\title{
Effect of carbon dioxide and hydrostatic pressure on the pH of culture media and the growth of methanogens at elevated temperature
}

\author{
Günther Bernhardt ${ }^{1}$, Albert Distèche ${ }^{2}$, Rạiner Jaenicke ${ }^{1}$, Benoît Koch ${ }^{2}$, Hans-Dietrich Lüdemann ${ }^{1}$, and \\ Karl-Otto Stetter ${ }^{3}$ \\ ${ }^{1}$ Institut für Biophysik and Physikalische Biochemie, Universität Regensburg, D-8400 Regensburg, Federal Republic of \\ Germany \\ ${ }^{2}$ Laboratoire d'Océanologie, Institut de Chimie, Université de Liège, B-4000 Liège, Belgique \\ 3 Institut für Biochemie, Genetik und Mikrobiologie, Universität Regensburg, D-8400 Regensburg, Federal Republic of \\ Germany
}

Summary. High pressure/high temperature investigations on thermophilic methanogens require specific precautions to provide well-defined $\mathrm{pH}$ conditions in their culture media. Applying $\mathrm{CO}_{2}$ as carbon source, sufficient buffering capacity of the culture medium is of crucial importance in investigations involving elevated pressures. In order to separate pressure effects on the growth and reproduction of thermophilic methanogens from pressure-induced protonation/deprotonation and increased solubility of gaseous components, direct $\mathrm{pH}$ measurements in common culture media in the absence and in the presence of $\mathrm{CO}_{2}$ were performed at elevated temperature $\left(65^{\circ} \mathrm{C}\right)$, and at pressures up to $100 \mathrm{MPa}$. Neutral phosphate buffer at high pressure shows a significant downward shift of its $\mathrm{pH}$ which is strongly enhanced in the presence of $\mathrm{CO}_{2}$. In minimal media containing acetate, carbonate, formate and phosphate in $\leqslant 100 \mathrm{mM}$ concentrations, $120 \mathrm{mM}$ HEPES is found to provide optimum $\mathrm{pH}$ stability: near neutrality the $\mathrm{pH}$ change upon $\mathrm{CO}_{2}$ saturation in the absence and in the presence of HEPES amounts to $\Delta \mathrm{pH}=2.10$ and 0.41 , respectively; the corresponding pressure dependences are $\Delta \mathrm{pH} / 100$ $\mathrm{MPa}=-0.26$ and -0.07 . As taken from these results, the apparent pressure dependence of the optimum growth of Methanococcus thermolithotrophicus at $65^{\circ} \mathrm{C}$ in minimal medium reflects the $\mathrm{pH}$ shift below the cutoff point of growth $\mathrm{pH}$ 5.5), rather than pressure-induced growth inhibition. At constant $\mathrm{pH}$, elevated pressure up to 400 $\mathrm{MPa}$ is found to increase the rate and yield of growth; at the same time, alterations in the phenotype of the bacterium are observed.

Offprint requests to: Rainer Jaenicke, Biochemie II, Universität Regensburg, Universitätsstrasse 31, D-8400 Regensburg, FRG

\section{Introduction}

The viability of microorganisms in their natural habitat depends in a complex way on the various environmental parameters. No general rules have been uncovered which would describe how temperature, pressure, $\mathrm{pH}$ and water activity cooperate in a synergistic or antagonistic way. What seems established is that the range of $\mathrm{pH}$ tolerance is narrowed with increasing hydrostatic pressure (Heefner 1982; Campbell et al. 1985). In defining the limits of temperature, Baross and Deming (1983) postulated the liquid state of water to be a necessary and sufficient requirement for life. Since elevated pressure favours the liquid state, one might expect that high pressure may broaden the temperature range of viability. In following this idea, hyperthermophilic microorganisms with optimum temperatures around $100^{\circ} \mathrm{C}$ (Stetter, 1985, 1986; Stetter et al. 1986) cause severe technical problems. These refer (i) to the corrosive effects of the gaseous sustrates (e.g. $\mathrm{H}_{2}$ or $\mathrm{H}_{2} \mathrm{~S}$ ), and (ii) to the problem of establishing well-defined growth conditions at high pressure and high temperature.

Concerning (i), high-pressure equipment for growing extreme thermophiles on gaseous substrates at high temperatures has been recently developed (Bernhardt et al. 1987). In connection with (ii), investigations on thermophilic methanogens require specific precautions, because $\mathrm{CO}_{2}$ as common carbon source strongly promotes the down-shift in $\mathrm{pH}$ reported for phosphate, bicarbonate or neutral minimal media at elevated pressure (Neumann et al. 1973; Jaenicke 1983, 1987).

The solubility of $\mathrm{CO}_{2}$ in water is affected by pressure and temperature in an antagonistic manner. Quantitative data in the range $0-50^{\circ} \mathrm{C}$ refer mainly to water and simple binary systems (Lan- 
dolt-Börnstein 1962). The influence of electrolytes and organic substances in aqueous solution on the solubility of gases has been discussed by Schumpe et al. (1982). For complex microbial culture media with numerous components neither solubilities nor $\mathrm{pH}$ determinations are available. In common biochemical fermentation processes, the total pressure is usually not far from atmospheric pressure. Under this condition, Henry's law is sufficient to quantify gas solubilities. Under high pressure/high temperature conditions, no predictions can be made, especially because the increase in gas solubility is parallelled by the increased dissociation of weak acids, due to the electrostrictive effect of ion formation. For the given reasons, in the present paper an attempt is made to measure the effect of $\mathrm{CO}_{2}$ and high hydrostatic pressure on the $\mathrm{pH}$ of a number of culture media at elevated temperature.

\section{Materials and methods}

\section{Bacterial cultures}

The thermophilic archaebacterium Methanococcus thermolithotrophicus has its temperature maximum at $70^{\circ} \mathrm{C}$; under optimum temperature conditions, at $65^{\circ} \mathrm{C}$, its doubling time is ca. $55 \mathrm{~min}$. Inoculation of a $5 \%$ bacterial suspension in $20 \mathrm{ml} \mathrm{me}$ dium was performed in serum flasks containing a gas mixture of $80 \% \mathrm{H}_{2}$ and $20 \% \mathrm{CO}_{2}$ at $0.2 \mathrm{MPa}$ (Huber et al. 1982). For high pressure experiments, the inoculum was transferred into nickel tubes in an anaerobic chamber. Gas exchange and high pressure experiments were performed as described elsewhere (Bernhardt et al. 1987).

\section{Media and substances}

The following culture media were applied:

$M G G$ : (minimal medium): $0.34 \mathrm{~g} \mathrm{KCl}, 4.30 \mathrm{~g} \mathrm{MgCl}_{2} \cdot 6 \mathrm{H}_{2} \mathrm{O}$, $3.46 \mathrm{~g} \mathrm{MgSO}_{4} \cdot 7 \mathrm{H}_{2} \mathrm{O}, 0.26 \mathrm{~g} \mathrm{NH} \mathrm{NH}_{4} \mathrm{Cl} 0.14 \mathrm{~g} \mathrm{CaCl} \cdot 2 \mathrm{H}_{2} \mathrm{O}$, $0.14 \mathrm{~g} \mathrm{~K}_{2} \mathrm{HPO}_{4}, 18.0 \mathrm{~g} \mathrm{NaCl}, 5.0 \mathrm{~g} \mathrm{NaHCO}_{3}, 10 \mathrm{ml}$ mineral salts, according to Balch et al. (1979), $1.0 \mathrm{ml} \mathrm{Fe}\left(\mathrm{NH}_{4}\right)_{2}\left(\mathrm{SO}_{4}\right)_{2}$ $(0.2 \%), 1.0 \mathrm{ml}$ Resazurin $(0.1 \%), 0.50 \mathrm{~g} \mathrm{Na}_{2} \mathrm{~S} \cdot 9 \mathrm{H}_{2} \mathrm{O}$, with water ad $1000 \mathrm{ml}$.

$M G^{-}$: MGG plus $0.5 \mathrm{~g}$ cysteine $\cdot \mathrm{HCl}, 1.0 \mathrm{~g}$ sodium acetate and $10 \mathrm{ml}$ vitamins, according to Balch et al. (1979).

$M G: \mathrm{MG}^{-}$plus $1.0 \mathrm{~g}$ yeast extract, $1.0 \mathrm{~g}$ peptone.

$M G^{-}$HEPES: $\mathrm{MG}^{-}$plus $120 \mathrm{mM}$ HEPES.

$M G^{-}$PIPES: $\mathrm{MG}^{-}$plus $54 \mathrm{mM}$ PIPES.

Chemicals were obtained from Merck (Darmstadt). HEPES from Sigma (München), and cysteine $\cdot \mathrm{HCl}$ from Fluka (Basel). Quartz bidistilled water was used throughout. The $\mathrm{pH}$ of the media was adjusted to $\mathrm{pH} 6.9$ before autoclaving and gas exchange at room temperature.

\section{Methods}

For high pressure autoclaves, as well as equipment for pressurization and pressure/temperature control, c.f. Schade et al.
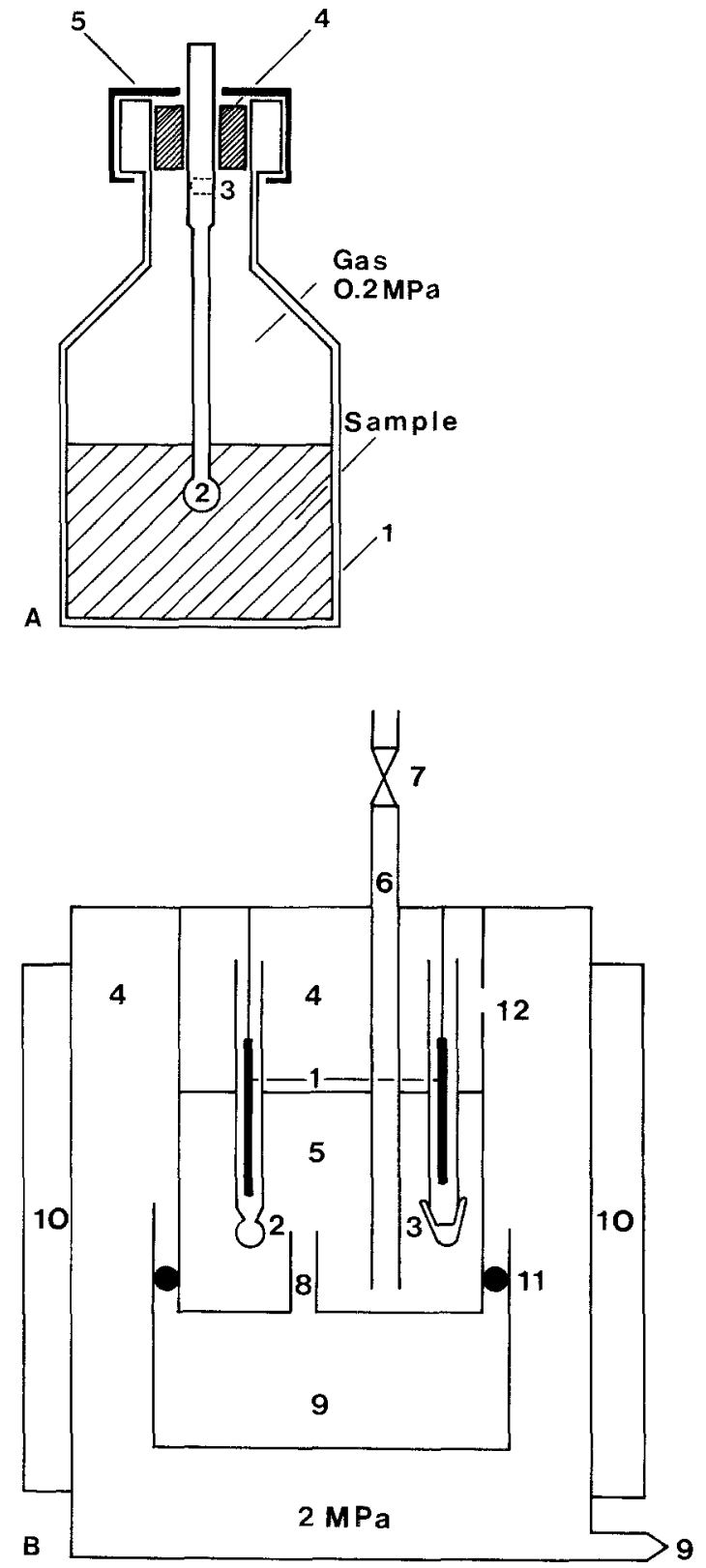

Fig. 1. A Device for $\mathrm{pH}$ determination under normal fermentation conditions: $65^{\circ} \mathrm{C}, 0.2 \mathrm{MPa} \mathrm{H}_{2} / \mathrm{CO}_{2}$. 1, serum flask; 2, $\mathrm{pH}$ electrode; 3 , bore-hole to equalize outside pressure; 4 , chlorobutyl cautchouk stopper; 5, aluminum cap. B. Device for $\mathrm{pH}$ determination at high pressure in the presence of gases. $1, \mathrm{Ag}-\mathrm{AgCl} ; 2, \mathrm{pH}$ glass electrode; 3 , reference electrode; 4 , silicon oil; 5 , sample; 6 , gas supply; 7 , valve; 8 , connecting tube; 9 , pressure supply; 10 , heating system; 11 , Oring; 12 , pressure balancing inlet

(1980) and Bernhardt et al. (1987). $\mathrm{pH}$ profiles of bacterial growth were measured in serum flasks supplied with a microelectrode (Ingold, Frankfurt, type 405-M3) (Fig. 1A) connected to a digital pH-meter (Knick, Berlin, type 643). To monitor the EMF a W \& W recorder (W \& W Electronic Inc., Basel) was applied. The electrode was calibrated at 20 and $65^{\circ} \mathrm{C}$ using acetate and phosphate standard buffers at $0.2 \mathrm{MPa} \mathrm{N} \mathrm{N}_{2}$ or $\mathrm{H}_{2}$. 
Altering the gases and the pressures (from atmospheric pressure to $0.2 \mathrm{MPa}$ ) had no effect on the $\mathrm{pH}$; the same holds for $\mathrm{Na}_{2} \mathrm{~S}$ as an additive interacting with the electrode $(t \leqslant 6 \mathrm{~h})$.

$\mathrm{pH}$ measurements at high pressure and $65^{\circ} \mathrm{C}$ made use of an electrochemical cell designed for high pressure/high temperature work (Fig. 1B) (Distèche 1959, 1962, 1972, 1974; Dogan et al. 1987). The electrochemical description of the cell is as follows:

$$
\begin{aligned}
& \mathrm{Ag}-\mathrm{AgCl}\left|\begin{array}{c}
{\left[\mathrm{H}_{3} \mathrm{O}^{+}\right]_{\mathrm{i}}=10^{-2}} \\
\mathrm{HCl}+\mathrm{NaCl} \\
\mathrm{I}_{\mathrm{i}}=\mathrm{I}_{\mathrm{r}}=\mathrm{I}_{\mathrm{s}}
\end{array}\right| \begin{array}{c}
\text { glass } \\
\text { membrane }
\end{array} \\
& \left|\begin{array}{c}
\text { sample } \\
{\left[\mathrm{H}_{3} \mathrm{O}^{+}\right]_{\mathrm{s}}=?} \\
\mathrm{I}_{s}
\end{array}\right| \begin{array}{c}
\text { liquid } \\
\text { junction }
\end{array}\left|\begin{array}{c}
\mathrm{H}_{2} \mathrm{O}+\mathrm{NaCl} \\
\mathrm{I}_{\mathrm{r}}=\mathrm{I}_{\mathrm{i}}=\mathrm{I}_{s}
\end{array}\right| \mathrm{AgCl}-\mathrm{Ag}
\end{aligned}
$$

where $I$ is the ionic strength, $i, r, s$ refer to the $\mathrm{pH}$ glass electrode, the reference electrode and the sample to test, respectively.

Since all culture media contained $0.41 \mathrm{~N} \mathrm{Cl}^{-}$, the chloride concentration of both electrodes had to be adjusted to $0.41 \mathrm{~N} \mathrm{Cl}^{-}$: Reference electrode $0.41 \mathrm{~N} \mathrm{NaCl}$, glass electrode $0.41 \mathrm{~N}^{2}$ total $\mathrm{Cl}^{-}$(containing $0.01 \mathrm{~N} \mathrm{HCl}$ ). This way the cell is built to minimize the junction potential and to give a highly stable electromotive force which permits to detect $0.001 \mathrm{pH}$ variations. The calibration is made by measuring the asymmetry and the slope of the electrode at the ionic strength of the solution to test. This was accomplished by titrating a solution of $\mathrm{Na}_{3} \mathrm{PO}_{4}-\mathrm{NaCl}$ with $\mathrm{HCl}$. The slope of the electrodes used was $\mathrm{S}_{1}=57.93 \mathrm{mV} / \mathrm{pH}$ unit at $\mathrm{pH} 2.0-7.2$, and $\mathrm{S}_{2}=57.25 \mathrm{mV} /$ $\mathrm{pH}$ unit at $\mathrm{pH} 7.2-8.5\left(25^{\circ} \mathrm{C}\right)$. The corresponding temperature factors are $S_{1} / K=0.194$ and $S_{2} / K=0.192$, respectively. The absolute value of $\mathrm{pH}$ can be measured with an accuracy of $0.01 \mathrm{pH}$ unit. The $\mathrm{pH}$ was calculated from the corrected electromotive force $\left(\mathrm{EMF}_{\mathrm{c}}\right)$, i.e. the measured $\mathrm{EMF}$ minus the asymmetry potential, according to

$\mathrm{pH}=-\frac{\mathrm{EMF}_{\mathrm{c}}}{\mathrm{S}}+2$

The temperature was measured using a two-terminal IC temperature transducer AD 590 (Analog Device).

In order to quantify bacterial growth at high temperature and high pressure, cell counting in a Neubauer chamber with $0.0025 \mathrm{~mm}^{2}$ area and $0.02 \mathrm{~mm}$ depth (Zeiss phase-contrast microscope) was applied.

\section{Results and discussion}

The metabolic energy of Methanococcus thermolithotrophicus is based on the equation

$$
4 \mathrm{H}_{2}+\mathrm{CO}_{2} \rightarrow \mathrm{CH}_{4}+2 \mathrm{H}_{2} \mathrm{O}
$$

The stoichiometry of the reaction suggests the reaction volume to be negative, independent of the culture medium. In contrast to the expected enhancement of growth, elevated hydrostatic pressure is found to inhibit the growth of Methanococcus under optimum conditions, even at moderate pressure. As shown in Fig. 2, the limiting

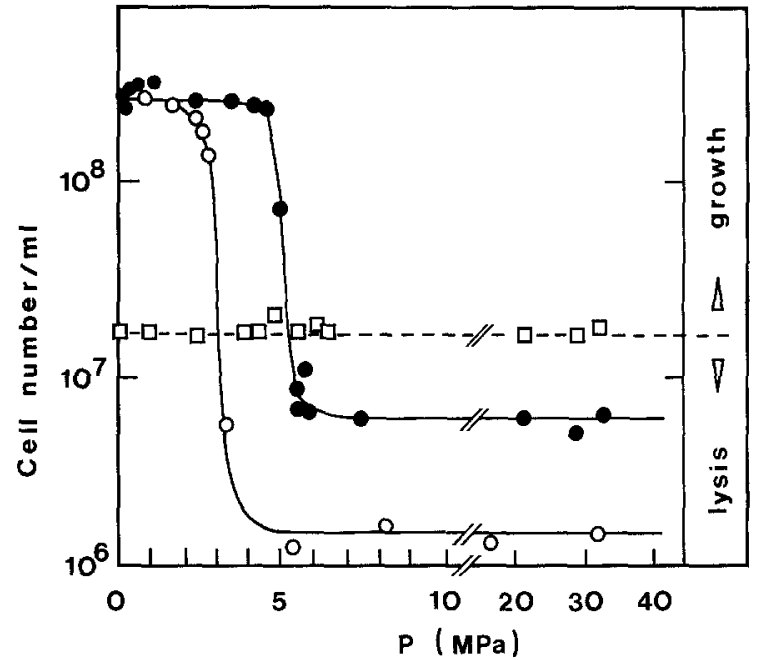

Fig. 2. Pressure effect on the growth of Methanococcus thermolithotrophicus in unbuffered standard media, MGG and MG. $4 \mathrm{ml}$ inoculum (pH 6.9) plus $6 \mathrm{ml} \mathrm{H}_{2} / \mathrm{CO}_{2}(0.4 \mathrm{MPa})$ were incubated at $65^{\circ} \mathrm{C}$ during $20 \mathrm{~h} . \mathrm{pH}$ was measured before the gas mixture was added. (O) MGG, (๑) MG, ( $\square$ ) initial cell number before pressurization

pressure where cell lysis outruns growth varies significantly in different culture media. The actual growth inhibition is even more dramatic, because differentiating intact cells and cell fragments is difficult so that the determination of cell numbers gives systematically too high values. It is reasonable to assume that at high pressure, where the cell number drops below the inoculation density, no intact cells are left. Applying culture media enriched by the addition of yeast extract, peptone, vitamins, sodium acetate and cysteine, the range of viability is shifted to higher pressures. Since part of the given additives act as weak buffers, one may assume that the increased stability is caused by restricting the pressure-induced acidification. In fact, Methanococcus thermolithotrophicus exhibits a significant growth inhibition at $\mathrm{pH}<5.5$ (cf. Fig. 3C).

In order to increase the buffer capacity, various buffer substances were investigated with respect to their influence on the growth of Methanococcus thermolithotrophicus at elevated temperature. Imidazole turns out to inhibit the growth even at low concentration ( $25 \mathrm{mM}, \mathrm{pH} 6.9)$. Since most organic buffer components show high enthalpies of ionization, i.e. a strong temperature dependence of their pH, PIPES and HEPES were chosen as promising candidates. Their characteristics are

PIPES pK ${ }_{\mathrm{a}}\left(20^{\circ} \mathrm{C}\right)=6.80 \quad \Delta \mathrm{pK}_{\mathrm{a}} / \mathrm{K}=-0.0085$ HEPES $\mathrm{pK}_{\mathrm{a}}\left(20^{\circ} \mathrm{C}\right)=7.55 \quad \Delta \mathrm{pK}_{\mathrm{a}} / \mathrm{K}=-0.014$ 

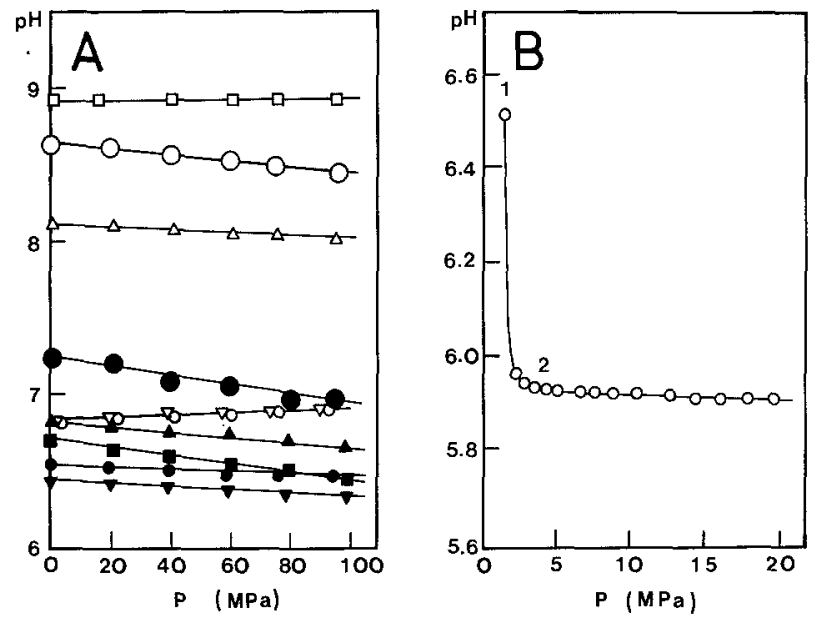

Fig. 4. Pressure effect on standard media at $65^{\circ} \mathrm{C}$ in the absence and presence of $\mathrm{CO}_{2}$. A. Pressure effect on the $\mathrm{pH}$ of $\operatorname{MGG}(O, \bullet), \operatorname{Mg}(\triangle, \Delta), \mathrm{MG}^{-}(\square, \boldsymbol{\square}), \mathrm{MG}^{-} \operatorname{PIPES}(\nabla$, $\nabla)$ and $\mathrm{MG}^{-} \operatorname{HEPES}(\circ, \bullet)$. Open symbols, in the absence of $\mathrm{CO}_{2}$; closed symbols, in the presence of $\approx 14 \mu \mathrm{Mol} \cdot \mathrm{ml}^{-1} \mathrm{CO}_{2}$. B. Effect of $\mathrm{CO}_{2}$ on the pH of $\mathrm{MG}^{-} \mathrm{HEPES}$ buffer at $65^{\circ} \mathrm{C}$. $40 \mathrm{ml}$ buffer were preincubated at $2 \mathrm{MPa}$; after reaching a stable EMF, addition of $20 \mathrm{ml} \mathrm{CO}$ at $3 \mathrm{MPa}$ (1) causes a pH shift of $\approx 0.6 \mathrm{pH}$ units. A further increase of hydrostatic pressure results in a marginal $\mathrm{pH}$ shift only (2)

media at high pressure and high temperature in the presence of $\mathrm{H}_{2} / \mathrm{CO}_{2}$, and (ii) the $\mathrm{pH}$ profile of growth, given in Fig. 3C, the pressure dependence of the cell number of Methanococcus thermolithotrophicus at optimum $\mathrm{pH}$ can now be established. As shown in Fig. 5A, high pressure in the range of up to $40 \mathrm{MPa}$ enhances cell proliferation, provided the $\mathrm{pH}$ does not drop below $\mathrm{pH} \approx 5.6$. In unbuffered (MGG) and insufficiently buffered (PIPES) media, the downward shift of the $\mathrm{pH}$ leads to the above mentioned apparent pressure inhibition at 3 and $7 \mathrm{MPa}$, respectively. At $p>40$
Table 2. Effect of $\mathrm{CO}_{2}$ and hydrostatic pressure on the $\mathrm{pH}$ of growth media at $65^{\circ} \mathrm{C}$

\begin{tabular}{lllllll}
\hline Medium $^{\mathrm{a}}$ & $\mathrm{pH}$ & & $\Delta \mathrm{pH}^{\mathrm{c}}$ & \multicolumn{2}{c}{$\Delta \mathrm{pH} / 100 \mathrm{MPa}$} \\
\cline { 2 - 3 } \cline { 5 - 7 } & $-\mathrm{CO}_{2}$ & $+\mathrm{CO}_{2}^{\mathrm{b}}$ & & & $-\mathrm{CO}_{2}$ & $+\mathrm{CO}_{2}^{\mathrm{b}}$ \\
\hline $\mathrm{MGG}$ & 8.65 & 7.25 & 1.40 & -0.13 & -0.30 \\
$\mathrm{MG}$ & 8.11 & 6.86 & 1.25 & -0.09 & -0.23 \\
$\mathrm{MG}^{-}$ & 8.80 & 6.70 & 2.10 & +0.04 & -0.26 \\
$\mathrm{MG}^{-}$HEPES & 6.82 & 6.41 & 0.41 & +0.06 & -0.07 \\
$\mathrm{MG}^{-}$PIPES & 6.84 & 6.52 & 0.32 & +0.05 & -0.07 \\
\hline
\end{tabular}

a cf. Materials and methods

b $\max \mathrm{CO}_{2}$ concentration $14 \mu \mathrm{Mol} \cdot \mathrm{ml}^{-1}$

c Decrease of $\mathrm{pH}$ after adding $14 \mu \mathrm{Mol} \cdot \mathrm{ml}^{-1} \mathrm{CO}_{2}$

$\mathrm{MPa}$, and constant $\mathrm{pH}$ (HEPES), elongation and other morphological alterations of the cells become visible, and beyond $100 \mathrm{MPa}$, lysis occurs (Fig. 5B).

\section{Conclusions}

The metabolic energy of Methanococcus is essentially based on two gaseous substrates both of which cause specific problems in high pressure/ high temperature experimentation. Handling hydrogen at $p \leqslant 200 \mathrm{MPa}$ and $>60^{\circ} \mathrm{C}$ causes severe permeability problems which have been successfully addressed by applying nickel tubes as containers for bacterial growth (Bernhardt et al. 1987). Carbon dioxide, together with high pressure ionization of common standard buffers, leads to a significant downward shift of the $\mathrm{pH}$ of growth media which may cause growth inhibition.

Since no $\mathrm{pH}$ values for typical growth media
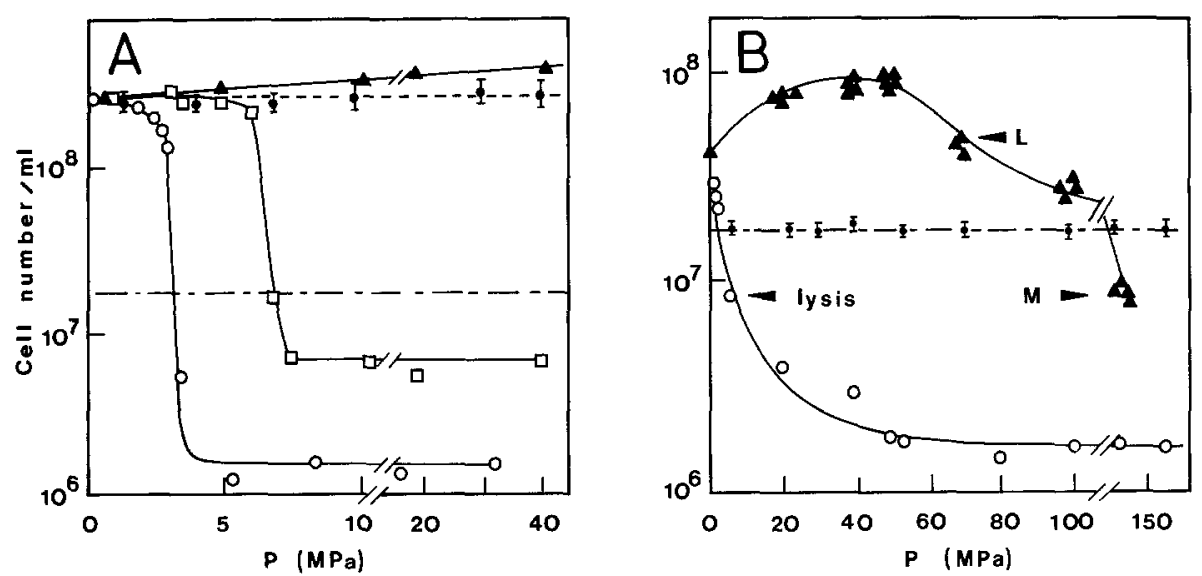

Fig. 5. Pressure effect on the growth of Methanococcus thermolithotrophicus in unbuffered and buffered minimal media at $65^{\circ} \mathrm{C}$. A. Bacterial growth at moderate

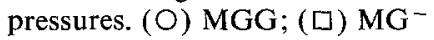
plus $54 \mathrm{mM}$ PIPES; (A) $\mathrm{MG}^{-}$ plus $120 \mathrm{mM}$ HEPES; (\$) initial cell number: controls without external pressure. Conditions as in Fig. 1. B. Bacterial growth at high hydrostatic pressure. (O) $\mathrm{MG}^{-} ;$( $) \mathrm{MG}^{-}$plus $120 \mathrm{mM}$ HEPES. Conditions as in Fig. 1, except $5 \mathrm{~h}$ incubation ( $\$$ ) initial cell number. L, anomalously elongated large cells; $M$, "mini cells" (vesicles?) 
at high pressure and high temperature have been tabulated, the respective data had to be determined before high pressure effects on the growth of methanogenic bacteria at high temperature could be approached. For Methanococcus thermolithotrophicus, optimum buffer conditions were obtained using $\mathrm{MG}^{-}$medium (Balch et al. 1979), supplemented with $120 \mathrm{mM}$ HEPES. Measurements of the growth rate of the bacterium in this medium exhibit biphasic characteristics: Below 40 $\mathrm{MPa}$, cell proliferation is enhanced without detectable alterations in the size and shape of the cells. Beyond $40 \mathrm{MPa}$, elongated, large sized cells are formed. Similar anomalies have been reported for a number of microorganisms exposed to high pressure at ambient temperature (ZoBell and Cobet 1964). Further increase of pressure finally causes cell lysis, again confirming previous observations (ZoBell 1970). The question whether high pressure may extend the range of viability of thermophilic organisms cannot be answered by the present experiments. Studies devoted to this question are in progress.

Acknowledgements. Financial support by the Deutsche Forschungsgemeinschaft (SFB 4, project F5) and by the Fonds der Chemischen Industrie is gratefully acknowledged. We thank the mechanical workshop, especially Mr. R. Knott, G. Niesner, $\mathrm{G}$. Wiesener and $\mathrm{K}$. Zweckerl, for skilled cooperation. $\mathrm{pH}$ glass electrodes were generously provided by Dr. A. E. Bottom (Kent Industrial Measurements Ltd, England).

\section{References}

Balch WE, Fox GE, Magrum LJ, Woese CR, Wolfe RS (1979) Methanogens: Reevaluation of a unique biological group. Microbiol Rev 43:260-296

Baross JA, Deming JW (1983) Growth of "black smoker" bacteria at temperatures of at least $250^{\circ} \mathrm{C}$. Nature $303: 423-426$

Bernhardt G, Jaenicke R, Lüdemann H-D (1987) High-pressure equipment for growing methanogenic microorganisms on gaseous substrates at high temperature. Appl Envir Microbiol 53:1876-1879

Campbell J, Bender GR, Marquis RE (1985) Barotolerant variant of Streptococcus faecalis with reduced sensitivity to glucose catabolite repression. Can J Microbiol 31:644650

Distèche A (1959) $\mathrm{pH}$ measurements with a glass electrode withstanding $1500 \mathrm{~kg} / \mathrm{cm}^{2}$ hydrostatic pressure. Rev Scient Instr 30:474-478
Distèche A (1962) Electrochemical measurements at high pressures. J Electochem Soc 109:1084-1092

Distèche A (1972) Effects of pressure on the dissociation of weak acids. Symp Soc Exp Biol 26:27-60

Distèche A (1974) The effect of pressure on dissociation constants and its temperature dependency. In: Goldberg E (ed) The Sea, vol 5: Ideas and observations. Wiley, New York, pp 81-121

Dogan A, Koch B, Vinson JM, Peyrus JC (1987) Design, construction and use of a system of "in situ" measurement of $\mathrm{pH}$ in a deep borehole. Health Physics (in press)

Heefner DL (1982) Transport of $\mathrm{H}^{+}, \mathrm{K}^{+}, \mathrm{Na}^{+}$and $\mathrm{Ca}^{2+}$ in Streptococcus. Mol Cell Biochem 44:81-106

Huber H, Thomm M, König H, Thies G, Stetter KO (1982) Methanococcus thermolithotrophicus, a novel thermophilic lithotrophic methanogen. Arch Microbiol 132:47-50

Jaenicke R (1983) Biochemical processes under high hydrostatic pressure. Naturwissenschaften $70: 332-341$

Jaenicke R (1987) Cellular components under extremes of pressure and temperature: Structure-function relationship of enzymes under pressure. In: Jannasch HW, Marquis RE, Zimmerman AM (eds) Current perspectives in high pressure biology. Academic Press, London, pp 257-272

Landolt-Börnstein (1962) Zahlenwerte und Funktionen aus Physik-Chemie-Astronomie-Geophysik-Technik: $\$ 2226$ Lösungsgleichgewichte, 6. Aufl. Springer, Berlin, Bd II/ $2 \mathrm{~b}: 1-28$

Neumann RC Jr, Kauzmann W, Zipp A (1973) Pressure dependence of weak acid ionisation in aqueous buffers. $J$ Phys Chem 77:2687-2691

Schade BC, Lüdemann H-D, Rudolph R, Jaenicke R (1980) Reversible high pressure dissociation of lactic dehydrogenase from porcine muscle. Biochemistry 19:1121-1126

Schumpe A, Quicker G, Deckwer W-D (1982) Gas solubilities in microbial culture media. In: Advances in biochemical engineering, Fiechter A (ed) Springer, Berlin, pp 1-38

Stephen H, Stephen T (eds) (1963) Solubilities of inorganic and organic compounds, vol 1 , part 1 and 2, Pergamon Press, Oxford, pp 365-368, 925

Stetter KO (1985) Extrem thermophile Bakterien. Naturwiss $72: 291-301$

Stetter KO (1986) Bakterielles Leben an der oberen Temperaturgrenze. Forum Mikrobiologie 9:15-19

Stetter KO, Fiala G, Huber R, Huber G, Segerer A (1986) Life above the boiling point of water? Experientia $42: 1187$ 1191

Westcott CC (1978) pH-measurements, Academic Press, New York, $\mathrm{p} 91$

ZoBell CE, Cobet AB (1964) Filament formation by Escherichia coli at increased hydrostatic pressure. J Bacteriol $87: 710-719$

ZoBell CE (1970) Pressure effects on morphology and life processes of bacteria. In: Zimmerman, AM (ed) High pressure effects on cellular processes. Academic Press, New York, pp $85-130$

Received November 5, 1987/Accepted November 9, 1987 